\title{
Miranda
}

Revue pluridisciplinaire du monde anglophone /

Multidisciplinary peer-reviewed journal on the English-

speaking world

$8 \mid 2013$

In Umbra Voluptatis : Shades, Shadows, and their

Felicities / Film Adaptations, New Interactions

\section{Dark Continent - Representations of Female Sexuality in Patrick White's The Eye of the Storm}

\section{Xavier Pons}

\section{(2) OpenEdition}

\section{Journals}

\section{Electronic version}

URL: http://journals.openedition.org/miranda/3407

DOI: $10.4000 /$ miranda.3407

ISSN: 2108-6559

\section{Publisher}

Université Toulouse - Jean Jaurès

\section{Electronic reference}

Xavier Pons, "Dark Continent - Representations of Female Sexuality in Patrick White's The Eye of the Storm", Miranda [Online], 8 | 2013, Online since 28 June 2013, connection on 16 February 2021. URL: http://journals.openedition.org/miranda/3407 ; DOI: https://doi.org/10.4000/miranda.3407

This text was automatically generated on 16 February 2021

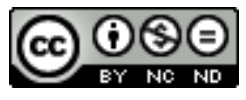

Miranda is licensed under a Creative Commons Attribution-NonCommercial-NoDerivatives 4.0 International License. 


\title{
Dark Continent - Representations of Female Sexuality in Patrick White's The Eye of the Storm
}

\author{
Xavier Pons
}

1 Physicist Stephen Hawking recently confessed that to him women were "a complete mystery" (Guardian, 4 January 2012) while Freud averred that "[t]he sexual life of adult women is a 'dark continent' for psychology" (Freud 212) and was reported by his friend and biographer Ernest Jones to have declared that "[t]he great question that has never been answered, and which I have not yet been able to answer, despite my thirty years of research into the feminine soul, is 'What does a woman want?"' (Felman 73). Women, their desire and sexuality, then remain enigmatic to heterosexual men, confirming de Beauvoir's insight, as reported by Judith Butler, that "to be a woman within the terms of a masculine culture is to be a source of mystery and unknowability for men" (Butler vii).

2 Perhaps the insights of a gay man are closer to the mark, even though Patrick White wrote, albeit ironically, of "the mystery of woman" (White 1957, 404). When he says of his minor character Colonel Hebden that "[f]or a man, he was extraordinarily interested in women" (414) we are to understand that in the novelist's opinion (straight) men are generally too obtuse and self-centred to achieve the degree of empathy that might shed some light on the mystery. That white himself evinced much greater empathy has a good deal (though not everything) to do with his homosexuality, one aspect of which was his belief in the existence in him of a feminine element, much as homosexual author Hans-Christian Andersen wrote of "the femininity of [his] nature" (Larivière) : as White's biographer David Marr averred, "[a]t the heart of his understanding of himself was the sense that there was a woman in this man" (Marr 75). His dabbling with Jungian notions, especially those of animus and anima, which hold that all human beings carry in themselves the image of the other sex, would have comforted him in his belief about the feminine element in himself-and the assorted benefits this conferred. While this does not amount to the "hermaphroditism of the 
soul" that Foucault rejected (Foucault 43), it may facilitate empathy and understanding. More problematically, it may also encourage the illusion that a man can achieve an insider's view of womanliness.

3 Having little or no sexual attraction to women is not the same as having no interest in their sexuality. Indeed, his exploration of this topic, like Voss's exploration of the Australian outback, was in many respects an exercise in self-discovery. White transferred some of his own psychological features to his female characters-thus his fascination with the virility suggested by hairs on a man's wrist, ascribed to Laura Trevelyan and Elizabeth Hunter as well as Eddie Twyborn-but, perhaps more importantly, he used his gifts as a writer of fiction to achieve, through the imagination, insights into realities that lay outside of mere experience. As a writer no less than as a person, White was very much interested in sex. "I feel more and more that creative activity in the arts is very closely connected with sexual activity, and that an awful lot of the insights I have had come from that source", he once confessed (Marr 486). This suggests not only that, unsurprisingly, his own sexual activity mattered a good deal to him but also that understanding other people's attitudes and practices where sex is concerned played a significant part in his approach to writing. He felt well enough equipped to produce representations of the sexual life of his characters, convinced as he was that by virtue of being a homosexual, he could achieve a unique understanding of men as well as women: "I recognised the freedom being conferred on me to range through every variation of the human mind, to play so many roles in so many contradictory envelopes of flesh", he wrote in his autobiography. (White 1981, 35). He was later to refer to his "various roles and sexes" (Marr 622), anticipating Judith Butler's contention that gender is a performance. The sexual passions of his female characters are not necessarily his own but are in a complex relationship with his own, which they all at once reflect, magnify and justify.

4 It is not likely that White derived his understanding of female sexuality from the women in his life. He did have many female acquaintances and friends, starting with his Scottish nurse Lizzie Clark who had an abiding love for him, and including such a variety of figures as Margery Williams, Nin Dutton, Cynthia Nolan or Maie Casey. But the relationships he had with them, however close, was not of the kind to yield any great insights into their sex lives. One would be tempted to take White at his word and attribute those insights solely (or mostly) to his homosexual sensibility and imagination if it was not for the towering figure of his mother Ruth. Not that she made confessions of a sexual nature to her son but her authority and drive tended to overshadow her rather colourless husband Dick and thus etched a broad pattern of female dominance in Patrick's mind. It has often been observed that a combination of strong mother and weak or absent father characterizes the background of many homosexuals and, because of the difficulties in identifying with a male figure, had something to do with their sexual orientation. ${ }^{1}$ This orientation of course colours a man's relations with other men but also his perceptions of women. White has been said to have had a "fear of woman" (During 46) and Guy Davidson wrote of "his tendency to align female characters-especially mothers-with abjection" (Davidson 4). It might be more accurate to speak of White's ambivalence in this respect-his depiction of Elizabeth Hunter, while it hides nothing of the old woman's flaws, accords her much respect and at bottom her "monstrous" figure has more to do with the novelist himself than with his mother. The feminine was for him another facet of his complicated soul. 
5 The lack of acceptance of homosexuality by society when he was a young man resulted, David Marr wrote, in "distress, self-disgust, loneliness and self-pity" and as a result, "all his fiction explores the territory of pain that lies between sensuality and its expression, between lust and love" (Marr 600). This rather sombre perspective, grounded in his condition as a homosexual within an inimical social and cultural context, has influenced his depiction of heterosexual relations, and of women's sexuality. Perhaps one could apply to White's interpretation of female sexuality what he said about his insights into old age : as a young then middle-aged man he had written confidently about old people, convinced that he could put himself in their place and imagine what it was like to be old. But once he grew old himself, he realized this had not really been the case, and confessed "I wrote The Eye of the Storm from the outside" (Marr 621). Where female sexuality is concerned, and for all his insistence on the feminine in his self, White also wrote very much from the outside.

6 The story of Elizabeth Hunter has a great deal to do with sex-the sex that is, or more often was, performed as well as that which remained in the characters' minds, as when Elizabeth reflects that Dr Gidley is "the kind of man I might have enjoyed as a lover" (White 1973, 77). Marr has argued that in White's view sex plays second fiddle to love : it "offers relief from lust" but only love "makes sex bearable" and without it "White's men and women are left prey to the great hazard of self-disgust" (Marr 512). It is true that, with White as with many other artists, lust and the resulting sexual activity, are expressions of man's baser nature and thus need to be kept in check if one is to allow one's higher, that is spiritual, nature to find expression. But keeping them in check also means recognising their power, not pretending they do not matter or have been conquered and silenced. Just as in White's writing the vulgar combines with the poetic, in his conception the spirit needs to take account of the flesh, no matter how distasteful the exercise.

7 What kind of difference does it make when the flesh is female rather than male? In White's homosexual world there is sometimes a blurring of gender distinctions, with feminine terms such as "queen", "bitch" or "cunt" used to refer to men, generally in disparaging fashion-thus when (gay) writer Paul Bailey wrote a bad review of The Eye of the Storm, White hit back by declaring "she's a jealous bitch" (Marr 526). Using the feminine as an insult does not suggest a high degree of either empathy or sympathy. This is more of a standard homosexual turn of phrase than evidence of an actual contempt for women, but White's ambiguous image of the female sex transpires in a number of unflattering references ${ }^{2}$. Gay men often have problematic or conflictual relations with female figures, beginning with their mothers ${ }^{3}$, and to this extent White is true to type. The Eye of the Storm is focussed on a representation of White's mother Ruth, the model for Elizabeth Hunter-even her death sitting on her commode is modelled on Ruth's own death. ${ }^{4}$ But, just as Ruth's genes passed into Patrick, the portrait of Elizabeth is to some extent a portrait of the novelist too. The feminine and the masculine are actually entwined, and it is a very delicate task to try to separate them, as shown by the example of Eudoxia Vatatzes aka Eddie Twyborn aka Eadith Trist (White 1979). If one is to make sense of the way in which White depicts female sexuality one has to be reasonably clear about what is female and what is male in the author's representations of sex. This is not the place to go into queer theory's questioning of sexual essentialism but, bearing in mind Judith Butler's warning that "'woman' need not be the cultural construction of the female body, and 'man' need not interpret male 
bodies" (Butler 112), perhaps it is enough to simply take White at his word-"he" is for male and "she" for female, even though the two might, uneasily perhaps, inhabit the same body. The complexities of gender are addressed in the novelist's later works such as The Twyborn Affair (1979) or Memoirs of Many in One (1986), but in The Eye of the Storm there are few ambiguities or ironies in this respect, with the possible exception of two of the most ostentatiously feminine characters being given names with unmistakably masculine connotations, "Hunter" and "Manhood", as well as a reference to "fe-males" (White 1973, 49). While the dramatis personae all have their specific perversities, their gendered identities are fairly stable and straightforward, wholly male or female as the case may be, and overwhelmingly straight. White clearly did not share the poststructuralist view that sexual identity is a matter of discourse.

Inevitably, sex has a good deal to do with power. Seducing one's partners amounts to holding them in one's power, if only briefly-"having their way with them" as White put it (77)-but the novelist hardly suggests that women are by nature the weaker sex : they, or at least some of them, can give as good as they get when they manage to overcome their inhibitions. Nor does he, in The Eye of the Storm, engage very much with the way sex and class interact, as he was to do in A Fringe of Leaves. Class issues are mostly raised in relation to the female characters and have little bearing on sexual issues, by which they are as it were transcended.

It is appropriate to start with the issue of desire or lust which is generally the underpinning of sex. It is sometimes held to be stronger, or at least more overtly expressed, in men than in women, whose respectability depends on hiding it ${ }^{5}$ and who prefer to see it disguised as romance and thereby made acceptable, according to the advice one sailor gives another in Voss: "You are like a big cat, Dick. And that is just what ladies do not take to, some big stray tom smoodgin' round their skirts. Ladies like to fall in love" (White 1957, 102). The same image recurs in The Eye of the Storm where Elizabeth Hunter refers to "the tom-cat stench of male sweat" (White 1973, 31). Lust is not presented as a positive life force, an energy which can be put to constructive purposes. It is more like a wild beast that needs to be tamed and kept in its place so that love and affection might flourish. White expressed in personal terms his rejection of lust and his elevation of love, especially in the form of affection ${ }^{6}$, and his characters are in this sense his mouthpieces. As Elizabeth puts it, "[l]ooking back, lust is always difficult to understand. And ugly. One's own is uglier than anybody else's" (342). Her daughter Dorothy concurs, and suspects that "[l]ust and disgust are one, the same shooting pain, in both mind and body" (405).

Lust is associated with disgust because it has to do with the flesh. It is not that the flesh is necessarily off putting-it can be a source of empowerment too, and Mrs Hunter fondly recalls dinner parties when she was much younger: "Your shoulders were at their whitest then, the mirrors showed, and your cleavage, from one or two glances, at its most mysterious: at such moments you were superbly conscious of your own power" (89). Sex appeal is one thing, but White's female characters tend to be repelled by the physicalities of sex which act as a cold shower on their desire. Elizabeth Hunter, who in her prime was certainly not in thrall to primness, has no fond memories of her fling with Athol Shreve : "she had only done it as an essay in sensuality ; the hair alone disgusted her" (15). ${ }^{7}$ But then perhaps his moral deficiencies have something to do with that. 
11 Even when disgust is not an issue, lovemaking is presented as futile and ridiculous, like Elizabeth's and her husband Bill's as the latter

groped, stroked, fumbled, looking for some kind of confirmation through his hands, before thrusting up inside her to reach the secret she was keeping from him [...] She only realized how small he was as he lay wilted and sweating, rather fatty about the shoulders, his exhausted lungs still battering at her practically pulverized breasts (28).

12 The reader will learn that in all their nights together Mrs Hunter never touched her husband's penis (224). Strangely enough under the pen of a male homosexual, the male body, and the penis in particular (though not the testicles...), are presented as offputting, and not in the least erotic. For Elizabeth it is almost an instrument of torture designed to make her reveal her innermost self, while Flora imagines her boyfriend Col "running after, waving his thing to bludgeon her into childbirth and endless domestic slavery" (86). As in some feminist views, the penis is nothing but a weapon, an instrument of male power and thus inimical to women's freedom and well-being. ${ }^{8}$ The euphemistic term "thing" suggests Flora's inability to achieve a positive view of the male sex. This representation may have something to do with White's difficulties in coming to terms with his own homosexual desire as a teenager ${ }^{9}$-not that he ever had any doubts about his orientation but the social context, especially in Australia, made this orientation something that must remain decently hidden, if not denied. His negative view of reproductive sex, ${ }^{10}$ however, does suggest a homosexual perspective.

More generally, and springing from much the same uneasiness with the body's materiality, these representations are part of the struggle of White's characters to be reconciled with the flesh, irrespective of whether it is male or female. Laura Trevelyan, at the beginning of Voss, cannot stand the body of her servant Rose Portion:

Kindness made [Rose's] whole body express her gratitude, but it was her body that repelled [...] It is the bodies of those servants, [Laura] told herself in some hopelessness and disgust (White 1957, 52-53).

She will later evolve and recognize some merit in bodies. But in much the same way Dorothy Hunter remembers sex with her husband with disgust-“the dreadful intimacies forced on her by the man with whom she still considered herself spiritually united" (White 1973, 410). This perspective is of course ascribed to frustrated women and has a good deal to do with their dissatisfaction. But in White's fiction the body often stands opposed to the spirit, and is a kind of dead weight that prevents the latter from soaring. The struggle between the two is one of the major dramas the novelist depicts, and is very much present in The Eye of the Storm : as critic Mark Williams noted of Elizabeth Hunter, "[s]piritual aspiration and gross carnality, mysticism and heresy, the desire for transcendence and unbearably nostalgic memories of physical love-all these opposites continually entwine" (Williams 127).

15 For all its repulsiveness, the flesh will not be denied. It does have its good points, like the pleasures of orgasm, which in Dorothy's eyes redeems the indignities of sex : "Even in the early days, while her marriage was still officially considered a success, she might have dismissed sexual love if it had not been for the sense of gratitude a rare climax produced in her" (White 1973, 54). As the word "rare" suggests, this is of course backhanded praise-the body, and sex, are more often a burden than a source of pleasure.

16 And yet the body is inescapable: human beings have to make do with it, whether they like it or not. Voss believed he "could dispense with flesh" and reach a state where 
"[a]ll twisted lusts had gone out of his body" (White 1957, 34, 213) but this was an illusion, one that Elizabeth Hunter does not share. Bodily concerns remain with us to the very end, as is illustrated by her dying while sitting on her commode. It is not actually possible to deny the flesh and its lusts. Over the normal course of a human life sexual infidelities are well-nigh inevitable, as when Mrs Hunter seduces her solicitor, Arnold Wyburg: "On her part it was only desire" (White 1973, 38). Lust is strong enough to overcome loathing of the physical, she finds when she has sex with Athol Shreve : "Disgust for his body, his exploratory hands, the rasp of hair against her skin, did not diminish her own lust" (99). Perhaps disgust is a cultural conditioning, a notalways-effective ruse to stop women from indulging their lust and to keep them virtuous, but this is not what White suggests.

However disparaged on many occasions, lust remains a persistent issue in old age, as White ruefully discovered when the time came. ${ }^{11}$ For all the shortcomings of sex, a preoccupation with it accompanies women throughout their lives-even advanced old age does not put an end to it, as is shown by Elizabeth Hunter's many mentions of the topic in conversations with her daughter and her nurses.

Mark Williams contends about The Eye of the Storm that "[i]n the dichotomy of flesh and spirit, sensuality and sensibility, that runs through the novel, the former is never denigrated" (Williams 131). This, as we have seen, is not quite the case, for the flesh is mostly presented as an inconvenience. But in White's mind there is indeed a great deal that is compelling about it and its cravings. This is despite its ugliness-indeed White seldom if ever celebrates the physical beauty of either sex-which is not even redeemed by love for one's partner, as appears from Elizabeth's viewing of her naked husband after sex "as he lay wilted and sweating, rather fatty about the shoulders" (White 1973, 28). This makes sexual desire something of a mystery, at least where women are concerned. It is the irrational or instinctual self and in this sense a counterpart of the mystical self-perhaps the latter could not exist without the former.

The most sexually active female character in the novel is nurse Flora Manhood. As Mark Williams put it, "[w]ith her golden skin, perspex ear-rings and violently coloured dress, she looks the mindless sensualist constructed by the old woman and her envious, frustrated daughter" (Williams 124). But her attitudes to sex are in fact full of contradictions. She enjoys the knowledge that she is physically attractive-she has to resist "the temptation to contemplate her own body" (White 1973, 84)-but she generally prefers the joys of imaginary sex to the reality of it. She resents "the greasy old men coming off shifts and out of pubs, scabby, horny men" (307) who ogle her on the bus-to be the object of their lust is most unpleasant. Perhaps it is those men's unsuitability as potential lovers that puts her off, although there is a basic ambiguity about her desires, as appears from the fact that the things she likes include the oxymoronic "making love; not making love" (84). She is perfectly capable of engaging in sex without having first been bowled over by an attractive man, as she demonstrates when she sleeps with Basil with the sole purpose of getting pregnant by him. Basil, with typical male vanity, thinks Flora is love-struck, enamoured of his looks, his fame or his title, and would be dismayed if he had access to her true thinking: "Here was this strange, not bad, but boring man, unconscious of the part he was playing, or the child she could conceive by him, regardless of whether he, or the child, wished it" (321). Flora is quite matter of fact when it comes to actual sex and she only grows romantic when the sex is in her imagination-her dreams, for instance: 
You couldn't say she hadn't been what they call "chaste" for some time now, though that didn't mean she hadn't let her mind roam around a bit, or hoped that some completely satisfying dream might descend upon her during sleep (308). for the imagination rather than for the body, as Elizabeth contends..$^{12}$ It is the imagination which turns the rather ludicrous fumblings of sexual encounters into a thrilling experience-but the imaginative flight cannot be sustained for ever, and this leads to revulsions of feeling when the facts of the matter emerge in all their starkness and displace the former epiphany. Thus Flora feels rather foolish for having set so much store by sex with her boyfriend: "It was too much spontaneity which persuaded her for a time that she needed Colin Pardoe. I am not whole Col except when I feel you inside me then we are truly one person, she had been fool enough to even put it in writing" (306). The afterglow or occasional ecstasy brought on by $\operatorname{sex}^{13}$ does not last, and White would seem to subscribe to the old saying that post coitum animal triste ${ }^{14}$. When sexual reality fails to live up to one's expectations, the imagination may turn sour and produce repulsive fantasies, as Flora's example again suggests:

To sleep with some hairy foreigner (Yes I did it Col with my eyes open I am my own mistress aren't I knowing all the dangers-the risk of venereal disease which is actually what I have caught-syphilis has been diagnosed) (177).

Although there is a positive element in those fantasies ("I am my own mistress") the negatives clearly predominate: physical ugliness, the lack of any truly personal connection with one's partner ("some hairy foreigner") and of course the dangers to one's physical integrity. Such fantasies can only give satisfaction to one's masochistic tendencies; like Mary de Santis' visions of sex with Basil (174) they highlight the character's frustrations. Flora is haunted by a fear of losing control of her life-as she says to Wyburd, “I no longer know what I really want. I don't seem to have control over myself" (278) - and this fear informs her attitude to sex.

It appears that women are frightened of their own desire which amounts to a loss of control, an immoral, dehumanising surrender to animal instincts-their own as well as their partner's. Denying those instincts is a way for them to assert their respectability, and thus their genuine femininity. For Elizabeth to touch her husband's penis "would have shown, wouldn't it ? [...] Or would it have seemed-whorish ?" (224). As for Flora, even while she is having sex with Basil-but this is for the respectable (?) purpose of becoming pregnant-she moans "I am not oh God oh Col I'm not the fucking whore you

think" (316). The figure of the whore, treated with much greater sympathy in The Vivisector (1970) and The Twyborn Affair (1979), is here utterly negative because viewed from a woman's perspective. This censorious perspective, also in evidence when Dorothy dismisses Flora as "the gaudy strumpet" (White 1973, 434), has nothing to do with mercenary attitudes, with the selling of one's body, and everything with putting shame or modesty aside to freely enjoy sex. For the women in The Eye of the Storm this is clearly unacceptable.

There is a manipulative element in all expressions of sexuality, White suggests, and this element is more marked where women are concerned-it is of course harder for men to feign desire. But in the end it is sometimes impossible to know who is manipulating whom. When Flora seduces Basil, there is an element of sincerity in the two of them, the sincerity of "each other's inquisitive lust" (314). Yet at the same time they are playing a part-Basil to reassure himself about his attractiveness to women, and Flora to get herself pregnant, and thus "to create something tangible, her only means of self- 
justification" (316). Paradoxically, Flora resorts to sex in order to achieve that which in itself sex is incapable of, "unselfish love" (315). Whatever their respective motives, Flora and Basil-unsurprisingly on the part of a competent actor-are giving "a great performance" (316), but a completely fruitless one as it turns out.

White appears to paint a rather glum picture of female sexuality, made worse by the contemptuous attitude ascribed to some male characters towards women. Thus Basil:

Come to think of it he had never been "adored" by any but unattractive girls who came to the performance night after night, and hung about the stage door blushing through chlorosis or acne; or by some elderly, often deformed woman usually without means, whose permanent, near stall was her one shameless extravagance, in which she sat devouring with her eyes, her open dentures, perving on a cod piece (319).

Can female sexuality be reduced to alternative examples of blushing, foolish virgins or deformed old harridans? This is Basil's jaundiced view, and hardly more than a caricature. In any case most women are not groupies of one kind or another. It would be unfair to regard White as unsympathetic to female sexuality because of his mostly negative views on lust. Nor does he suggest that sexual desires and practices are the same in all women.

White had an inclination to view the body as an embarrassment rather than an asset.

But he also recognized that it can be a source of pleasure, as Dorothy experiences: "how exotic, how naked her body felt when the southerly began to blow at the end of a sticky summer's day, caressing her inside her dress" (65). But she is far too puritanical to be able to abandon herself to sensual pleasures, as appears from her response to the sight of a young couple miming sex in a park :

...she crossed her ankles, and might have enjoyed contemplating her classic Pinet shoes if it hadn't been for a young couple stretched on the grass, in a bay scalloped from the evergreens. The young people were conducting themselves disgracefully, with the result that they impinged on the thoughts of the princess, till she too was writhing, upright and alone on her bench, in almost perfect time with their united, prostrate bodies.

It was ghastly (271).

This scene illustrates the point made by David Marr in his account of White's schooldays at Tudor House: "From his time in this oasis of sensuality, grass and sex were forever coupled in his imagination" (Marr 60). More importantly perhaps, it highlights the potential of sex to unite human beings. It is the lovers' bodies that are united here but the sympathetic way in which they are described (if only because Dorothy seemingly disapproves of them but at bottom envies them) suggests that the harmony between them goes beyond the merely physical. Female sexuality in particular may lead to the "surrender to selflessness" that White mentioned in Voss (White 1957, 48) and that the German explorer found so disgusting at first. In this sense, the female approach to sex differs from that of men who, as Belle Bonner puts it, "fall in love, over and over again, but it is always with themselves" (120).

White's characters distinguish quite broadly between lust and love-as Mrs Hunter puts it, "love is not a matter of lovers" (White 1973, 170). Lust is self-centered, having no purpose but its own gratification whereas love amounts to a discarding of all selfish preoccupations and is thus a path to transcendence. This is why Flora craves a child, "who would be the embodiment of unselfish love" (315) while Mary de Santis believes that "love is a kind of supernatural state to which I must give myself entirely, and be 
used up, particularly my imperfections-till I am nothing" (162). This mystical view makes love far superior to lust but White acknowledges that ideally the two should coexist, and that disembodied love is not achievable, except perhaps by saints. Dorothy refers to "sexual love" (54), suggesting that sex can sometimes transcend mere lust and thus promote growth, empathy, and make for valuable relationships between human beings.

After seducing her solicitor, Elizabeth reflects that "we don't love each other Arnold and I am the one to blame I don't love you but loved it it is something which had to which you will forget and I shall remember with pleasure" (38). It may be worth paying some attention to the phrase "I don't love you but loved it", with its significant disjunction between "you" and "it" and their common denominator "love". Actually, the verb does not mean quite the same in the two occurrences-one might speak of a "strong" sense in the first (love as in "Romeo loves Juliet") and a "weak" one in the latter (love as in "Jim loves fish and chips"). The difference is further emphasized by the variation in the tenses, from present to preterit. To love someone as it were suspends the passing of time (albeit provisionally in most cases), or lifts one above the flux of time, whereas to love something is an experience which remains inscribed within a specific moment and is devoid of any potential for transcendence. White puts sex in its proper place, exaggerating neither its virtues nor its shortcomings. He also highlights an important way in which men's approach to it differs from women's: "you will forget and I shall remember with pleasure." Men have sex and then are done with it whereas the experience, whether good or bad, continues to resonate with women. In this sense, sex paradoxically matters more to women-it is more of a defining force in their lives. Elizabeth's pleasurable memories appear to contradict her confession to her daughter : "Oh, I was unfaithful once or twice-but only as a sort of experiment-and it did prove it wasn't worth it" (77). Perhaps it is simply that White's characters, like real people and the author himself, are full of contradictions and their convictions evolve with the passing of time. Yet it seems more likely that the contradiction is inherent in the female approach to sex itself, encapsulated by the novelist's observation about Mary de Santis: "her own dichotomy of earthbound flesh and aspiring spirit" (209). Sex is a positive as well as a negative, bringing pleasure as well as pain, and neither aspect can be ignored.

The ambiguous relationship between lust and love is mirrored in the dialectic between lover and husband. In fiction, these are often presented as stock characters-the former being a romantic, exciting figure, and the latter rather tame and conventional, if not downright boring. Women achieve sexual ecstasy with a lover and respectability with a husband. This view has of course been challenged, in particular by Gustave Flaubert in Madame Bovary-one of the novels White most admired-where lover Rodolphe is shown to be a complete cad while husband Charles, for all his limitations, is a good, sincere and devoted man. In White's novel the stereotype is not so much turned on its head as deconstructed for hiding the complexities of the matter. Lover and husband are but two sides of the same inadequate but indispensable coin, and Elizabeth Hunter considers that neither is satisfactory : after asserting that "[f]or most women [...] sexual pleasure is largely imagination" she adds "[t]hey imagine lovers while their husbands are having their way with them, but in their lovers' arms they regret what they remember as the husband's humdrum virtues" (77). Sex with a husband is reduced to the man "having his way" with the woman, making the latter a passive, exploited object incapable of experiencing pleasure except by entertaining adulterous fantasies. 
But sex with a lover is hardly better since it is a source of regret. In either case, the woman craves the absent figure and is thus condemned to dissatisfaction. Ideally, husband and lover should be one and the same person but even when this is actually the case happiness remains out of reach. Reflecting on her daughter's dissatisfaction, Elizabeth considers that "[p]robably her trouble was that Hubert had been too much the lover for his wife to have experienced a husband" (78). Too much emphasis on physical pleasure is counterproductive-but so is too little emphasis, as when Elizabeth concludes that the fact she never touched her husband's penis signifies her failure to love him adequately. The very distinction between lover and husband seems to disappear when Flora refers to Col Pardoe as "her lover-tyrant" (112) or when Elizabeth embraces her husband after learning he has cancer : "they must have looked like lovers locked in one of the conventional attitudes of passion" (195). In romantic fiction lovers are often presented as a liberating force releasing women from the tyranny of domesticity, but this is clearly not how Flora feels. Besides, her use of the word "lover" is ambiguous since $\mathrm{Col}$ is not a fling but a steady boyfriend and a potential husband. If anything, it is Basil who is her lover-but he is described as "boring" (321) and Flora hopes he will give her a child: those are attitudes and expectations that are generally laid at a husband's, not a lover's door.

31 The distinction between the two disintegrates into a mess of contradictions. The alliance of love with lust is a consummation devoutly to be wished but it remains either unsustainable or out of reach. Women seem condemned to lurch from one to the other and back, always unsatisfied.

Men do not pay much attention to the negatives of sex-at any rate, this is not something that White emphasizes, unlike what he does in the case of women. Thus Elizabeth is afraid Arnold will find displaying his naked body such an embarrassment that it might interfere with performance, so she tries to reassure him by closing her eyes. But in fact "Arnold was not in need of inspiration. His heavy breathing exploded her theory" (38). The male approach to sex is fairly unproblematic, if not downright mechanical. Women, on the other hand, are much more complicated and ambiguous creatures. Even sensual Flora indulges in very negative sexual fantasies and while she's having sex with Basil she experiences a kind of dehumanization in spite of the notion that women are supposed to enjoy extended foreplay: "He was all over and around her : exploring. She felt she had stopped being a woman, to become a mountain range" (315).

Whether sex is regarded as life-enhancing or life-constricting, and whether an interest in sex lasts a lifetime or not, the fact is that some women appear to do entirely without it, leading chaste, celibate lives. Given the number of positively described spinsters in White's fiction-prominent examples include Theodora Goodman in The Aunt's Story (1948) and Miss Hare in Riders in the Chariot (1961)-one might conclude that White preferred his women sexless. Chaste Laura Trevelyan, the heroine of Voss, is also depicted in mostly positive terms but there is in that novel a suggestion that a virgin needs to develop into a woman-that is the normal path of growth, as appears from the description of Belle Bonner on her wedding day in terms of a caterpillar turning into a butterfly, "inside the shuddering, white cocoon from which she would emerge a woman" (White 1957, 330). Having actual sex may not be necessary for this metamorphosis, as Laura's example shows. She is referred to as a girl until she empathizes with her servant Rose Portion through corporeality and as a result she 
turns into a woman. At first the difference between the unexperienced and the experienced female is emphasized : "the girl could feel the woman's pulse ticking in her own body" ( 160 ; emphasis mine) but then this difference is abolished as Laura and Rose share the same womanhood: "the heat was so intense that the women's breath was taken from them" (161). Thanks to Rose, who helps her find the body acceptable, as well as her love for Voss, Laura becomes a woman and a mother, achieving a sublimated sexual life of her own. Complete spinsterhood has become less attractive, and this is confirmed in The Eye of the Storm where spinsters come in for a good deal of venom, as when Sister de Santis is referred to as "the passive mollusc, or solitary female" (White 1973, 334). Conversely, those women who have come to the end of their sexual life on account of menopause (an association which is no longer made but that still held some sway as recently as the 1970s) are the object of White's satire, as in this offhand observation: "The blue-haired women had got into some kind of menopausal huddle" (349) or in his describing a dog "whinging old womanishly" (489).

If renouncing sex is somehow unnatural, there are of course other kinds of transgressive sexual practices. As a homosexual himself, white could have been expected to give a fairly positive image of gay people, but this is far from being consistently the case. If Eddie Twyborn is treated with much sympathy, Cecil Cutbush, in The Vivisector (1970), is presented in starkly negative terms. In The Eye of the Storm White touches on the topic of female homosexuality with Flora's cousin Snow Tunks, who proves as unattractive as her name suggests when she feels the pain of her lover's desertion: "Snow Tunks began, not to cry, to trickle or dribble, gin or tears. With one hand she made a swipe at the silver sickle swinging from her mouth. Or nose" (569). White describes her in a consistently negative light and emphasizes all that is unnatural about her: not only is she an albino but as a teenager "she was growing muscles instead of tits" (179). Her manners are unappealingly masculine ("sitting, knees apart, like a man sits, the cigarette hanging from the skin of her mouth" (181) and are not redeemed by her vestigial femininity ("Snow was probably jealous, not as a man, which is bad enough, but something left over from being born a woman" (182). The kind of foreplay her lover Alix and she engage in is presented in cruel, caricatural manner : "Alix was rubbing up and down against Snow's backview like a grater on a lump of cheese" (183). White's disapproving stance in respect of lesbians-"this kitchenful of drunken women" (184)-is paradoxical in a homosexual but, as we shall see, may nonetheless be consistent with his approach to female sexuality.

There is no clearer instance of the nastiness of sex than incest, which is what Dorothy and Basil resort to in order to find some comfort but which of course fails to do the trick, especially after Basil points out the Oedipal character of the position they're in: "Do you realize, Dorothy, they probably got us in this bed?" (526). As Peter Wolfe observed, "in usurping their parents' roles, they believe they can wipe out the past and start anew. Their act backfires [...] The offspring of their sexuality is death, their mother dying at perhaps the exact time they are coupling" (Wolfe 187, 188).

Sex is the most revealing way of relating to other people, and when one is prey to selfdoubt, guilt or even self-hatred this is bound to distort the way one relates to others, especially where sex is concerned because in this intimate experience one lays oneself bare, at the risk of finding this vulnerability quite painful. Dorothy is a victim of selfhatred, and she never received the support which might have allowed her to overcome this, as appears during her visit to Kudjeri where she is surrounded by the affection of 
Ann Macrory and her daughters : "If she could have remained enclosed by this circle of love and trust, she might have accepted herself by living up to their opinion of her" (White 1973, 511). Mary de Santis is something of a masochist, as Richard Wilson underlined: "Sinning in thought only, she must yet exorcise her lust by 'a discipline of drudgery"' (Wilson 76). Even lusty Flora's sex life is made complicated by her uncertainties and hesitations.

Most female characters in The Eye of the Storm have given up sex. Elizabeth Hunter is in her late eighties and confined to what is practically her deathbed, so that her abstinence does not call for further explanations. Her take on sex is inevitably retrospective-and no less powerful for that. Dorothy, who is fifty, has "renounced men, at her age" (White 1973, 484) though she is occasionally troubled by desire ; Flora has been "what they call 'chaste' for some time now" (308), except for her seduction of Basil, because sex brings her more trouble than satisfaction and Mary appears to have remained a virgin, as befits her name, in order to focus on things spiritual. There is thus a marked contrast between the actual amount of sex narrated in respect of the characters' current condition and an ever present preoccupation with the subject in the characters' minds. This accords with White's conception that the sex that matters most takes place in the mind, as either imagination or memory. An a contrario confirmation is provided by Basil and Dorothy's incestuous lovemaking: their encounter was certainly not imagined in advance of the fact and appears to be completely erased from or cast out of their memories afterwards. It has no redeeming virtue and offers no perspective.

Despite all its limitations, and whether it is pursued or shunned, sex is a defining element in the female characters' lives. Elizabeth Hunter's mana, the power she exerts on her entourage right down to the end, has a good deal to do with her past sexual attractiveness. At the same time, her yearning for the transcendental experience in the eye of the storm, the provisional tranquility before passions are unleashed again, and the confession of some of her inadequacies, suggest that in order to be profitable sex has to be kept in its proper place-though what that is is never entirely made clear.

David Marr has suggested that after White won the Nobel Prize in 1973 his writing became "saturated with a late, relaxed sensuality" (Marr 552) which had until then been constrained or thwarted. Marr was referring in particular to such novels as A Fringe of Leaves (1976) and The Twyborn Affair (1979). The Eye of the Storm (1973), which came out in the year of the Nobel, in a sense foreshadows White's growing willingness to engage with sexual issues in his fiction. Not that a preoccupation with the topic was absent from his previous novels, but it was more allusive and more circumscribed. Afterwards, White will be able to engage in depictions of sex (whether heterosexual as in the case of Ellen Roxburgh or homosexual in the case of Eddie Twyborn ${ }^{15}$ ) that are far more positive in terms of its ability to give pleasure and enhance life.

White brought to the description of his female characters' sex lives some of the hangups he experienced as a gay man in a hostile social context. As that context became more tolerant over the years White found himself more capable of insisting on the virtues of sex. The Eye of the Storm is in this sense a transitional novel. If sexual pleasure is celebrated, it is in fairly understated fashion, with marked emphasis on its downsides. The novel, like its predecessors, leads to the conclusion that it is love rather than sex which enhances life. Sex without love can give a momentary thrill but does not amount to much. Yet it is an inescapable preoccupation, and discarding it is fraught 
with the risk of dessication. There is an unresolved tension, in the female characters, between acceptance of sex and rejection and this makes them different from the male characters : these-Athol Shreve, Arnold Wyburg, Col Pardoe or Basil Hunter-have sex whenever an opportunity offers and are not much troubled by ethical problems. In this sense White's novel offers a fairly conventional view of the differences between male and female sexuality. At the same time, by suggesting that women are actually more preoccupied with sex than men he challenges the prevailing stereotype. It is not just that women have sex on their minds but that their approach to the issue is far more complex than men's-men do not appear to connect sex with the getting of children, for instance. They are far more aware of issues such as the connections between sex and power or between sex and betrayal and as a result are less straightforward in their sexual practices, more inclined to revulsion or twinges of conscience. This makes them, in a way, more enlightened though not happier sexual creatures.

In order to identify what is specific in White's depiction of female sexuality, we might turn to Joan Riviere's concept of the masquerade, the notion that women need to disguise themselves, to wear a mask, in order to achieve womanliness, with the result that, as French psychoanalyst Marie-Hélène Brousse put it, "the only way of truly touching the feminine is the mask itself, not what lies behind" (Brousse 2000). Most of White's characters, men as well as women, are shown to be wearing masks in order to conform to this norm or that, and thus find it difficult to be themselves. Basil Hunter, the great actor, is a case in point but the mask is even more significant where women are concerned-men may wear a mask to play a particular role but women wear one just to be feminine. The chief masquerader is of course Elizabeth Hunter, who, in her younger days, is compared to "a jewelled scabbard in which a sword was hidden" (White 1973, 73), an image which contrasts an outer, decorative femininity with an inner steeliness with something phallic about it. She can hardly function without the protective cover of jewellery and make up-"I like to feel I have been made up", she says. "It fills me with-an illusion-of beauty" (42). Her emeralds and rings become a "green and silver mask" (541) and when, at the end of the day the mask is removed it is as if all life had gone out of her: "By now the image on the bed was stripped of vestments and jewels, the festive paint removed from its face. What remained might have been a corpse [...] The total effect did not suggest a woman" (151).

Her daughter shields herself by playing the role of a princess, dressed up in "her faithful old Chanel" (47), her "classic Pinet shoes" (63) and the "de Lascabanes pearls" (58). When she contemplates buying an expensive dress, it is in order to have "an armature to intimidate any possible adversary, and to warn off what could be worse, an importunate admirer" (286). The mask is both seductive and protective.

43 The role-playing inherent in the masquerade extends inevitably to the characters' sexuality, making it insincere and thus unfulfilling. Although Guy Davidson has argued that "White pretty much eschewed camp during his 'closeted' period" (Davidson 7) and that he truly attained camp style only with the uncloseting of the Twyborn Affair (Davidson 10), it is undeniable that theatricality, and thus a form of camp, plays a significant part in The Eye of the Storm. The OED defines camp as "ostentatious, exaggerated, affected, theatrical; effeminate or homosexual; pertaining to, characteristic of, homosexuals." Camp thus combines theatricality and homosexuality which makes it very relevant to White's approach to sex and literature, even before his coming out. Indeed, it could be argued that in his conception of female sexuality there 
is a good deal that results from a projection of the novelist's own sense of self-his female characters are "one of the many envelopes of flesh" (White 1973, 27) that White, like Mrs Hunter, had been wearing. Joan Riviere argued that it is above all "women who wish for masculinity" (Riviere 303) who resort to wearing a "womanly" mask, and this oscillation between the masculine and the feminine is at the heart of White's understanding of his own sexuality, which he transferred to many of his characters. The women in The Eye of the Storm wish to be "saved from desire", as Dorothy is said to be at the close of the novel (White 1973, 587) because desire leads them to the disturbing thoughts and practices that we have looked at, and results mostly in frustration or regret. Giving way to desire is dangerous because it entails a loss of control and perhaps of identity as well.

To say that those views are-or are not-an accurate representation of female sexuality would imply an essentialist conception of the latter. What they do is outline some of the possible ways in which gender identity is performed, part of a gamut that is broad enough to accommodate the projections and fantasies of a male homosexual novelist, part of an imaginary world in which male and female desires conflict and entwine but achieve no lasting resolution. If White depicted aspects of his own self through his female characters, especially when it comes to almost simultaneously breaking the rules of sexual propriety and playing by them, he did not so much transcend the sex divide as deconstruct it. Judith Butler argued that "the postulation of a true gender identity" turns out to be "a regulatory fiction" (Butler 141), and White, whose fiction is anything but regulatory, can be absolved of such a sin.

\section{BIBLIOGRAPHY}

Anon. "Post-Sex Blues Plague a Third of Young Women." Live Science. 30 March 2011. Last accessed 5 March 2012. <http://www.livescience.com/13487-women-post-sex-sadness.html>.

Brousse, Marie-Hélène. “ Qu'est-ce qu'une femme ? ” Le Pont Freudien. 2000. Last accessed 10 February 2012. <http://pontfreudien.org/content/marie-h\%C3\%A9l\%C3\%A8ne-brousse-quest-cequune-femme>.

Butler, Judith. Gender Trouble-Feminism and the Subversion of Identity. New York : Routledge, 1990.

Davidson, Guy. "Displaying the Monster : Patrick White, Sexuality, Celebrity". Australian Literary Studies $25: 1$ (2010) : 1-18.

During, Simon. Patrick White. Melbourne : Oxford University Press, 1996.

Felman, Shoshana. What does a woman want?: Reading and Sexual Difference. Baltimore : Johns Hopkins University Press, 1993.

Fenichel, Otto. The Psychoanalytic Theory of Neuroses. London : Kegan Paul, 1946.

Foucault, Michel, The History of Sexuality. vol. 1. New York : Pantheon, 1986. 
Freud, Sigmund. The Question of Lay Analysis. Standard Edition vol. 20. London : Hogarth Press, 1926. 183-250.

Jones, Ernest. Sigmund Freud : Life and Work. London : Hogarth Press, 1931.

Knudson, Mary. “When a Penis is a Weapon.” PLOS Blogs. 10 March 2011. 11 March 2013. <http:// blogs.plos.org/blog/2011/03/10/when-a-penis-is-a-weapon/>

Larivière, Michel. “ Andersen oublié par les fées.” 01 April 2011. Last accessed 10 February 2012. <http://gayscelebres.hautetfort.com/archive/2011/02/12/andersen-oublie-par-les-fees.html>.

Marr, David. Patrick White : A Life. Sydney: Random House, 1991.

Pons, Xavier. Messengers of Eros-Representations of Sex in Australian Writing. Newcastle : Cambridge Scholars Publishing, 2009.

Riviere, Joan, “Womanliness as Masquerade." International Journal of Psychoanalysis 10 (1929) : 303-323.

Sample, Ian. "Stephen Hawkins admits he finds women 'a complete mystery." The Guardian, 4 January 2012. Last accessed 3 February 2012. <http://www.guardian.co.uk/science/2012/jan/04/ stephen-hawking-women-complete-mystery>.

Sharp, Gwen. "Presenting the Penis as a Dangerous Weapon." 27 February 2010. 11 March 2013. $<$ http://thesocietypages.org/socimages/2010/02/27/presenting-the-penis-as-a-dangerousweapon-mildly-nsfw/>

West, D.J. 'Parental Figures in the Genesis of Male Homosexuality.' International Journal of Social Psychiatry 5 :2 (Autumn 1959) : 85-97.

White, Patrick. A Fringe of Leaves. 1976. Harmondsworth : Penguin, 1985.

---. Flaws in the Glass. London : Jonathan Cape, 1981.

---. Riders in the Chariot. New York : Viking, 1961.

---. The Aunt's Story. New York: Viking, 1948.

---. The Eye of the Storm. London : Jonathan Cape, 1973.

---.The Twyborn Affair. London : Jonathan Cape, 1979.

---.The Vivisector. New York : Viking, 1970.

---. Voss. 1957. Harmondsworth : Penguin, 1970.

Williams, Mark. Patrick White. London : Macmillan, 1993.

Wilson, Richard. “'The Splinters of a Mind Make a Whole Piece'-Patrick White's The Eye of the Storm." In Studies in the Recent Australian Novel. Ed. K.G. Hamilton. St Lucia : UQP, 1978. 61-83. Wolfe, Peter. Laden Choirs-The Fiction of Patrick White. Lexington : University of Kentucky Press, 1983.

\section{NOTES}

1. "Many clinicians, psychoanalytic and otherwise, have formed the same impression, namely that a disproportionate number of their male homosexual parents give a history of a dominating mother and a weak, unsatisfactory or absent father" (West 85). 
2. For example, Zillah Puttuck at the Cheesemans' party is "a hairless kangaroo-rat of a woman" (291); Dorothy is described "shivering like a bitch temporarily parted from her owner (whoever that might be) on a railway platform" (288).

3. "In quite a number of homosexuals, the decisive identification with the mother was made as an 'identification with the aggressor', that is in boys who were very much afraid of their mothers" (Fenichel 331).

4. "The core of Elizabeth Hunter was Ruth" (Marr 496).

5. "In general, Una preferred the other sex, though she was far too nice a girl to admit it to a diary, let alone a friend" (White 1957, 57).

6. See White's interview by Sally Beggbie on ABC television in 1990:

"How important is love to life?"

"It's all important-but not lust."

"What type of love is important?"

"Affection, I think. Yes, affection." (quoted in Marr 642). But love, despite its importance, is no less difficult than lust to negotiate, as Elizabeth Hunter recognized: "The worst thing about love between human beings [...] when you're prepared to love them they don't want it; when they do, it's you who can't bear the idea" (White 1973, 11).

7. See also Laura Trevelyan, who is both fascinated and repelled by signs of masculinity: "In this way she was able to avoid actual sight of the German, even if her mind's eye dwelt on the masculine shape of his lips, and his wiry wrist with the little hairs [...] He was terribly repulsive to her" (White 1957, 73).

8. See Sharp; or "when a penis is used for violence, it is no different from a gun or a knife or a club. In rape, the penis is a weapon" (Knudson).

9. David Marr writes of White's "self-disgust" and "self-loathing" largely linked to the discovery of his homosexuality (Marr 74, 75).

10. See the opinion ascribed to Flora: "All men, she suspected, not only Col Pardoe, hated the pill as being unnatural. It was natural for men, even if they didn't know it, to want to pump a woman up, then in watching, feel their self-importance expand" (White 1973, 309).

11. See David Marr writing about White in his seventies: "Desire had not let him go" (Marr 620).

12. "For most women, I think, sexual pleasure is largely imagination" (White 1973, 77).

13. The ecstasy is expressed here by the use of the pronoun "you" which humanizes the penis, unlike the word "thing" that Flora had used earlier.

14. A recent study of Australian women appears to confirm it ("Post-Sex Blues Plague a Third of Young Women").

15. See my discussion of A Fringe of Leaves in Pons 2009.

\section{ABSTRACTS}

Patrick White was a gay novelist with a marked interest in female sexuality, which he saw as a reflection of his own. Sex is a prominent topos in The Eye of the Storm: it is in White's eyes a fundamental dimension of human nature, though he generally views lust, as distinct from love, 
as a negative selfish force. But lust can be a source of pleasure too, and anyway it cannot be denied despite its repulsive aspects.

The compellingness of sex has more to do with the imagination than with the body which inevitably disappoints. For social and other reasons, White's female characters tend to be frightened of their own desires but are not above using sex to manipulate men, lovers no less than husbands. Sexual transgressions are inevitable in White's fiction because sex reveals one's true nature.

The Eye of the Storm places greater emphasis on sex than White's previous fiction, and can be seen as transitional, opening the way for the more overt explorations of sensuality in the novels that follow. Although his depiction of female sexuality is conventional in some respects, it also challenges many stereotypes : it is both sympathetic and critical.

Romancier homosexuel, Patrick White montre un grand intérêt pour la sexualité féminine, miroir de la sienne. La sexualité, dimension fondamentale de la nature humaine aux yeux de White, est très présente dans The Eye of the Storm. Le désir, différencié de l'amour par son égoïsme, est généralement présenté sous un jour négatif, mais il apporte aussi du plaisir, et ne peut être dénié malgré ses côtés répugnants. La force de la sexualité tient plus à l'imagination qu'au corps lui-même, source de déception. Pour des raisons sociales et autres, les personnages féminins de White ont peur de leur propre désir mais n'hésitent pas à se servir du sexe pour manipuler les hommes, amants comme maris. Les transgressions sexuelles sont inévitables car le sexe révèle la vraie nature des personnages. The Eye of the Storm insiste plus sur le sexe que les romans précédents de White, et s'avère ainsi transitionnel, ouvrant la voie à une exploration plus explicite de la sensualité dans les romans ultérieurs. Bien que White présente la sexualité féminine de manière conventionnelle à certains égards, il remet aussi en question certains stéréotypes : sa vision est à la fois compréhensive et critique.

\section{INDEX}

Mots-clés: sexe, pouvoir, désir, amour, féminité, performance, transgression

Keywords: sex, power, lust, love, femininity, performance, transgression

\section{AUTHOR}

\section{XAVIER PONS}

Université de Toulouse-Le Mirail

Professor Emeritus

pons@univ-tlse2.fr 